\title{
РАДІОФІЗИКА ГЕОКОСМОСУ
}

DOI: https://doi.org/10.15407/rpra25.04.276

УДК $550.385 .37: 550.388$

\author{
Y. LUO, Л. Ф. ЧОРНОГОР, К. П. ГАРМАШ
}

Харківський національний університет імені В. Н. Каразіна,

м. Свободи, 4, м. Харків, 61022, Україна

E-mail: Leonid.F.Chernogor@gmail.com

\section{ГЕОМАГНІТНИЙ ЕФЕКТ ТУРЕЦЬКОГО ЗЕМЛЕТРУСУ 24 СІЧНЯ 2020 р.}

Предмет і мета роботи: Головною причиною геомагнітних збурень є космічні джерела, процеси в сонячному вітрі та в міжпланетному середовищі, падіння великих космічних тіл. До геомагнітного ефекту призводять також землетруси. Згідно системної парадигми об 'єкт Земля - атмосфера - іоносфера -магнітосфера є єдиною системою, де мають місие прямі та зворотні, позитивні та негативні зв'язки. Механізм впливу літосферних процесів $і$ землетрусів на магнітне поле вивчений недостатньо. Вважається, щчо до изього впливу призводять розтріскування порід, флуктуюючий рух у поровій рідині, розряди статичної електрики тощо. Під час землетрусу генеруються сейсмічні, акустико-гравітаційні хвилі (АГХ) та магнітогідродинамічні (МГД) хвилі. Мета цієї роботи - опис магнітного ефекту землетруса, який мав місие 24 січня 2020 р. в Туреччині.

Методи та методологія: Вимірювання виконані за допомогою магнітометра-флюксметра. Він має високу чутливість $(0.5 \div 500$ пТл у діапазоні періодів коливань рівня геомагнітного поля $1 \div 1000$ с відповідно) $і$ досить широку смугу досліджуваних частот (від 0.001 до 1 Ги). Магнітометр IM-II підключений до спеціалізованого мікроконтролерного реєстратора, який виконує поцифрування та попередню фільтрацію магнітометричних сигналів на інтервалах 0.5 с, а також зберігає відфільтровані відліки і час їх отримання в USB флеш-пам'яті. Для детального дослідження квазіперіодичних процесів використовувався системний спектральний аналіз часових варіацій рівня Н $і$ D компонент геомагнітного поля. Він трунтується на одночасному застосуванні віконного перетворення Фур' $\epsilon$, адаптивного перетворення Фур 'є та вейвлет-перетворення. В останньому використовувався материнський вейвлет у вигляді функиї Морлє. Результати: Припускається, щуо спостережуваний 23 січня 2020 р. приблизно за 25.5 год до землетрусу иуг коливань у рівні D-компоненти міг бути пов'язаний з магнітним передвісником. Двохполярний імпульс в Н-компоненті 24 січня 2020 р. міг бути зумовлений поршневою дією землетрусу, який згенерував МГД імпульс. Квазіперіодичні варіації рівня Н і D компонент геомагнітного поля, щуо спостерігалися через 75 хв після землетрусу, були викликані генерацією магнітного збурення рухомими іоносферними збуреннями, зумовленими АГХ від землетрусу. Амплітуда магнітного ефекту була близька до 0.3 нТл, квазіперіод - до $700 \div 900$ с. За оиінками відносна амплітуда збурень концентрачії електронів у полі АГХ становила близько $8 \%$, а період - $700 \div 900$ с. Виявлено затухаючі коливання в обох компонентах магнітного поля з періодом близько 120 с. Припускається, щчо иеей ефект пов'язаний з генерацією ударної хвилі в атмосфері протягом землетрусу.

Висновок: Вивчено магнітні варіації в діапазоні періодів $1 \div 1000$ с, щз супроводжували підготовку землетрусу і саму сейсмічну подію.

Ключові слова: землетрус, магнітометр-флюксметр, квазіперіодичні збурення, сейсмічні хвилі, акустико-гравітаційні хвилі, МГД імпульс

\section{1. Вступ}

Основною причиною геомагнітних збурень $€$ космічні джерела, процеси в сонячному вітрі та в міжпланетному середовищі і падіння великих космічних тіл [1-9].

Атмосферні джерела, до яких відносяться грози, погодні фронти, циклони, торнадо та урагани, також дають свій внесок в геомагнітні збурення [10-12].

До геомагнітних ефектів призводять землетруси [13-24].
Помітні геомагнітні збурення супроводжують потужні вибухи [24-26], старти та польоти ракет [27-29], вплив на іоносферну плазму потужним радіовипромінюванням [30,31].

Далі зупинимося на геомагнітних збуреннях літосферного походження [13-23, 32, 33]. Згідно системної парадигми, об'єкт Земля - атмосфеpa - іоносфера - магнітосфера (ЗАIM) є єдиною системою, де мають місце прямі та зворотні, позитивні та негативні зв'язки [34-38]. Механізм впливу літосферних процесів і землетрусів на магнітне поле вивчений недостатньо. Вважається, 
що до цього впливу призводять розтріскування порід, флуктуюючий рух в поровій рідині, розряди статичної електрики тощо [15-23]. При землетрусах генеруються сейсмічні, акустико-гравітаційні хвилі (АГХ) та магнітогідродинамічні (МГД) хвилі (див., наприклад, [39-42]).

Цілу низку статей присвячено пошуку магнітних передвісників землетрусів.

Вперше на можливість існування геомагнітного передвісника землетруів вказав автор роботи [43] ще в 1964 р. За 1 год 6 хв до Великого землетрусу на Алясці (США) 27 березня 1964 р. 3 магнітудою $\mathrm{M} \approx 9.2$ він виявив короткочасне аперіодичне збільшення рівня геомагнітного поля на $\sim 100$ нТл. Виникнення цього ефекту він пояснював п'єзомагнітним ефектом порід, підданих стисканню. На жаль, результат автора [43] 3 тих пір жодного разу не підтвердився іншими дослідниками. Очевидно, що мав місце випадковий збіг двох подій.

3 1970-х рр. були розгорнуті широкомасштабні дослідження, спрямовані на пошуки геомагнітних передвісників землетрусів [14, 44-51]. Спочатку увага приділялася пошуку передвісників у вигляді імпульсного електромагнітного випромінювання.

На жаль, пошук магнітних передвісників землетрусів не завжди супроводжувався детальним аналізом геомагнітної обстановки та стану космічної погоди. Так, автор роботи [52] вважав, що він за три години до землетрусу Лома Прієта, що стався у Північній Каліфорнії у 1989 р., виявив поблизу епіцентру землетруса магнітний передвісник у діапазоні періодів коливань рівня геомагнітного поля $2 \div 100$ с (магнітуда землетрусу $\mathrm{M}_{s} \approx 7.1$ ). Автор іншої роботи [53] лише через 19 років після публікації статті [52], зіставивши варіації магнітного поля з варіаціями геомагнітних індексів $a_{p}$ і $D_{s t}$, дійшов висновку, що так званий “передвісник” був викликаний магнітною суббурею.

Автори роботи [54] повідомили, що вони за 3 год до землетрусу в Чилі, який мав місце 27 лютого 2010 p. ( $(\mathrm{N} \approx 8.8$, глибина - 34 км), виявили геомагнітний аперіодичний передвісник землетрусу. Тривалість передвісника становила 1 год, максимальне збурення індукції геомагнітного поля -690 нТл. Таке аномально велике значення передбачуваного ефекту мало б насторожити авторів. Незабаром з'явилася публікація [55], де переконливо було доведено, що геомагнітне збу- рення було пов'язане з суббурею, а не з землетрусом.

Інтерес до передвісників землетрусів в усіх підсистемах системи ЗАІМ різко виріс після Спітакського землетрусу, який стався 7 грудня 1988 р. ( $(\mathrm{\approx} \approx 6.9$, глибина - 6 км) та мав значні соціальні наслідки (див., наприклад, [56, 57]). На відстані 129 км від епіцентру Спітакського землетрусу амплітуда збурення індукції геомагнітного поля становила $\Delta B \approx 0.03 \div 0.2$ нТл, а період $-T \approx 1 \div 10$ с [57].

Крім передбачуваних передвісників імпульсного типу, можуть існувати квазіперіодичні геомагнітні провісники землетрусів. Так, наприклад, квазіперіодичні $(T \approx 20 \div 50$ c) геомагнітні передвісники обговорюються в роботах $[45,58-60]$. Такі передвісники нібито виникали за кілька діб до землетрусу. За даними [58] $\Delta B \approx 0.1$ нТл.

Новий сплеск інтересу до геомагнітних передвісників землетрусів виник у період публікацій статей [47-51], де в якості передвісників пропонувалося розглядати квазіперіодичні цуги коливань - ультранизькочастотні (УНЧ) електромагнітні збурення з періодами $40 \div 250$ с (тобто в діапазоні пульсацій Рc3, Pc4 і Рc5). Амплітуда передбачуваних передвісників становила $\approx 1 \div 5$ нТл [47-50]. Слабким місцем всіх робіт [47-50] $\epsilon$ відсутність детального аналізу стану космічної погоди, наприклад такого, як в роботі [55]. У той же час добре відомо, що періоди $40 \div 250$ с властиві геомагнітним пульсаціям космічного походження, які систематично реєструються наземними та космічними магнітометрами.

Механізм походження аномальних магнітних збурень, як підкреслюють автори [47-51], залишається нез'ясованим.

Протилежної точки зору дотримуються автори робіт [61-63]. На підставі власних досліджень УНЧ магнітних збурень у діапазоні періодів $0.1 \div 100$ с вони дійшли висновку, що спостережувані коливання пов'язані з процесами у верхній атмосфері та не мають відношення до землетрусів на стадії їх підготовки.

Певний скептицизм висловлюється й авторами робіт [53, 64-66]. Як переконливо продемонстрували автори статті [67], квазігармонічні УНЧ сигнали, описані в цілій низці робіт [47-50], швидше за все, мають магнітосферне походження. Таке ж походження мають і сигнали “передвісників”, описані в роботах $[45,68]$. 
Огляд можливих електромагнітних провісників землетрусів в УНЧ діапазоні виконано в роботі [64], а огляд механізмів магнітних збурень - в роботах [17, 23, 69, 70]. В оглядовій роботі [71], де викладено єдину концепцію підготовки сейсмічних подій, магнітний передвісник, на відміну від багатьох інших, взагалі не згадується.

Таким чином, у геофізиків немає єдиної думки про існування геомагнітного передвісника землетрусів. Якщо все ж він і існує, виявити його важко через низьке відношення сигнал/шум і через значне переважання геомагнітних варіацій космічного походження. Принциповим питанням $€$ механізм генерації квазіперіодичних магнітних передвісників землетруів, що мають досить велику амплітуду.

Лише нещодавно механізм магнітного передвісника землетруів запропоновано автором [33].

Мета цієї роботи - опис магнітного ефекту землетруса, що мав місце 24 січня 2020 р. в Туреччині.

\section{2. Загальні відомості про землетрус}

Землетрус магнітудою 6.7 і тривалістю 15 с стався о 17:55:14 (тут і далі всесвітній час, UT) 24 січня 2020 р. біля м. Сиврідж, провінція Елязиг, Туреччина, де проживає близько 4 тис. осіб. Від землетрусу постраждало 1547 осіб, а 35 осіб загинуло. Координати епіцентру наступні: $38.4^{\circ}$ пн. ш., $39.1^{\circ}$ сх. д. Глибина землетрусу становила 10 км.

\section{3. Засоби та методи спостереження}

Магнітометр-флюксметр. Основою магнітометричного комплексу, розташованого в с. Гракове, Харківська обл., Україна, (географічні координати: $49.65^{\circ}$ пн. ш., $36.9^{\circ}$ сх. д.), є індуктивний магнітометр-флюксметр IM-II розробки Інституту фізики Землі РАН. Він має високу чутливість $(0.5 \div 500$ пТл в діапазоні періодів $1 \div 1000$ с) і досить широку смугу досліджуваних частот (від 0.001 до 1 Гц). Магнітометр IM-II підключено до спеціалізованого мікроконтролерного реєстратора, який здійснює поцифрування та попередню фільтрацію магнітометричних сигналів на інтервалах часу $0.5 \mathrm{c}$, а також зберігає відфільтровані відліки і час їх отримання в USB флеш-пам'яті. Інформація про поточні дату та час, яка отримується від приймача GPS сигналів BR-304, що входить до складу комплексу, використовується для щодобової корекції власного енергонезалеж- ного (має незалежне батарейне живлення) годинника мікроконтролерного реєстратора. Завдяки цьому похибка часової прив'язки магнітометричних даних не перевищує декількох десятих часток секунди.

За допомогою зазначеного магнітометрафлюксметра ведуться безперервні спостереження за варіаціями рівня горизонтальних $H$ і $D$ компонент магнітного поля Землі.

Системний спектральний аналіз. Для детального дослідження квазіперіодичних процесів використовувався системний спектральний аналіз часових варіацій рівня $H$ і $D$ компонент геомагнітного поля [72]. Він грунтується на одночасному застосуванні віконного перетворення Фур'€ (ВПФ), адаптивного перетворення Фур'є (АПФ) та вейвлет-перетворення (ВП). В останньому використовувався материнський вейвлет у вигляді функції Морлє (див., наприклад, [72]). Як відомо, АПФ має кращу роздільну здатність за частотою (періодом), ніж ВПФ. У свою чергу, ВПФ властива краща роздільна здатність за часом. Важливо, що АПФ має незмінні відносні (нормовані на тривалість “вікна") розділення за часом і періодом при зміні значення відносного періоду. У той же час для ВПФ вони змінюються приблизно на порядок. ВП дозволяє “вирівняти шанси" складових з різними частотами (періодами). 3 цих причин спільне застосування ВПФ, АПФ та ВП дозволяє більш детально дослідити частотно-часову (періодно-часову) структуру різних фізичних процесів.

\section{4. Стан космічної погоди}

21 січня 2020 р. концентрація частинок у сонячному вітрі $n_{s w}$ збільшилась приблизно від $10 \cdot 10^{6}$ до $24 \cdot 10^{6} \mathrm{M}^{-3}$, а потім до кінця доби повернулась практично до незбуреного стану (див. рис. 1). 22 та 23 січня 2020 р. мали місце незначні флуктуації $n_{s w}$ (від $2.3 \cdot 10^{6}$ до $12 \cdot 10^{6} \mathrm{M}^{-3}$ ). Поблизу часу землетруса та наступної доби $n_{s w} \approx 10 \cdot 10^{6} \mathrm{M}^{-3}$. Швидкість частинок у сонячному вітрі $V_{s w}$ змінювалась від 290 до $360 \mathrm{~m} / \mathrm{c}$. Температура частинок у сонячному $T_{s w}$ вітрі 21 та 22 січня 2020 р. збільшувалась від $10^{4}$ до $10^{5} \mathrm{~K}$. Варіації тиску частинок у сонячному вітрі $p_{s w}(t)$ практично повторювали збурення $n_{s w}(t) .21$ січня 2020 р. значення $p_{s w}$ збільшились від 1 до 4 нПа. 23 та 24 січня 2020 р. значення $p_{s w}$ змінювалися від 1 до 2 нПа. Рівні $B_{y}$ та $B_{z}$ компонент міжпланетного геомагнітного поля 21 та 22 січня 2020 р. змінювались приблизно 


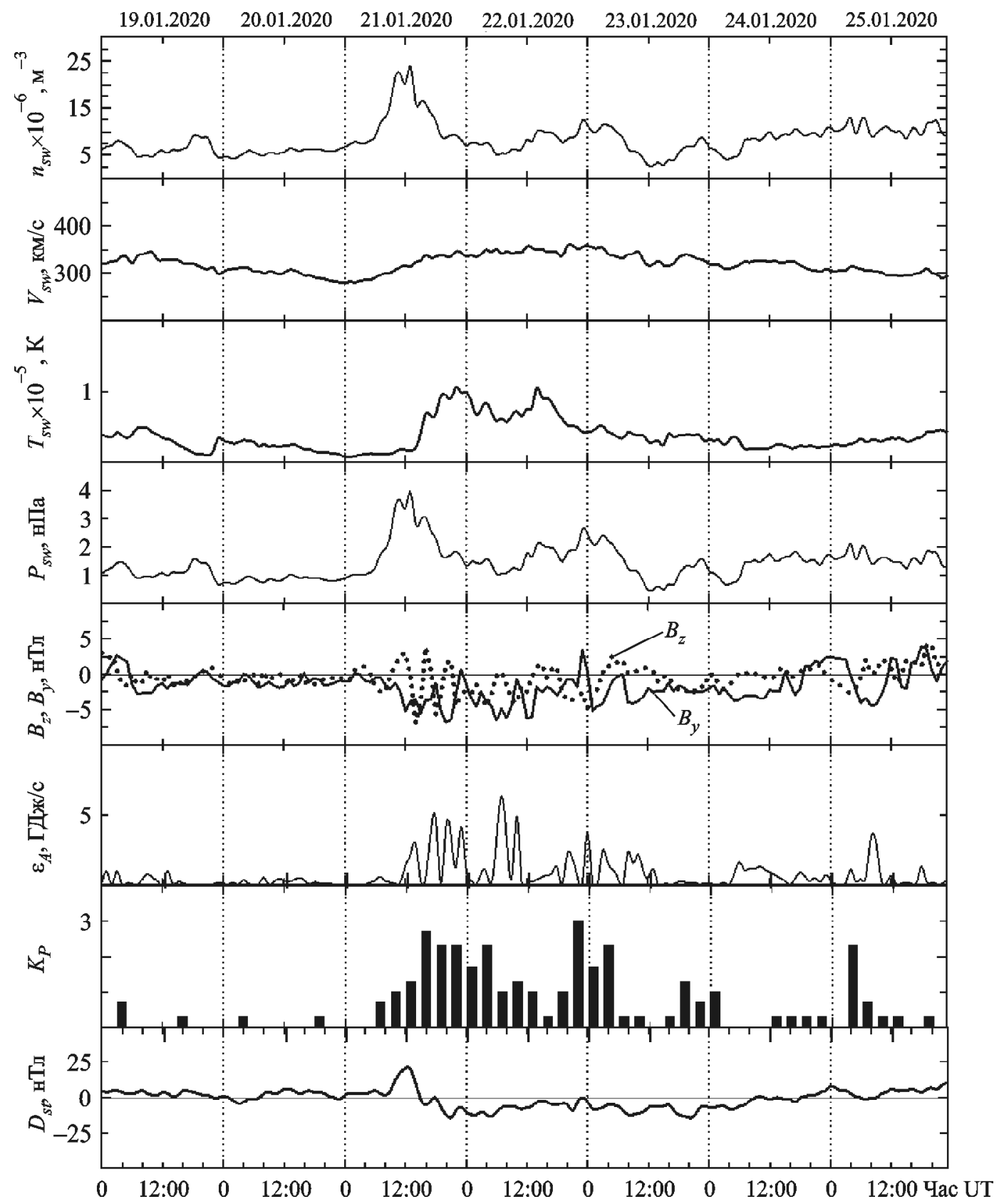

Puc. 1. Часові варіації параметрів сонячного вітру: виміряних концентрації частинок $n_{s w}$, температури $T_{s w}$, радіальної швидкості $V_{s w}$ (за даними сайта ftp://ftp.swpc.noaa.gov/pub/lists/ace2/) та розрахованого динамічного тиску $p_{s w},-$ а також виміряні компоненти $B_{z}$ та $B_{y}$ міжпланетного магнітного поля (за даними супутника GOES), розраховані значення енергії $\varepsilon_{A}$, що передається сонячним вітром магнітосфері Землі за одиницю часу, $K_{p}$-індексу та $D_{s t}$-індексу (за даними сайта http://wdc.kugi.kyoto-u.ac.jp/aeasy/) в період 19-25 січня 2020 р. Дати вказано вдовж осі абсцис

від -7 до +4 нТл. 23, 24 та 25 січня 2020 р. їх варіації не перевищували $\pm(3 \div 4)$ нТл. Помітні сплески (до 5 ГДж/с) функції Акасофу $\varepsilon_{A}$ мали місце 21 та 22 січня 2020 р. 24 січня 2020 р. варіації $\varepsilon_{A}$ не перевищували 1 ГДж/с. 21 та 22 січня 2020 р. значення $K_{p}$-індексу знаходились в межах $2 \div 3$. 24 січня 2020 р. $K_{p} \leq 0.3$. Приблизно в середині доби 21 січня 2020 p. $D_{s t}$-індекс збільшився до 21 нТл, а потім мало місце його зменшення до -14 нТл. Індекс мав від'ємні значення протягом 22 та 23 січня 2020 р. 24 січня 2020 р. $D_{s t} \approx 0$ нТл. 21 , 22 і 23 січня 2020 р. спостерігалась магнітна суббуря.

Таким чином, у день землетрусу магнітне поле було спокійним. Це дозволило виконати пошук 
магнітного ефекту землетруса, який мав місце 24 січня 2020 p.

\section{5. Результати аналізу}

Опишемо часові варіації рівня $H$ і $D$ компонент геомагнітного поля в день землетрусу, а також у контрольні дні (рис. 2-4).

3 рис. 2 видно, що 23 січня 2020 р. значення $H$ компоненти флуктуювали в межах $\pm(0.2 \div 0.3)$ нТл. Приблизно з 19:40 до 21:00 мало місце збільшення рівня флуктуацій до $0.4 \div 0.6$ нТл. При цьому в спектрі переважали коливання 3 періодами $T \approx 600 \div 1000$ с и $T \approx 300 \div 500$ с. Значення $D$-компоненти флуктуювали в межах \pm 0.2 нТл. Приблизно з 16:30 до 18:00 та з 19:30 до 21:00 амплітуда збільшилася до $0.4 \div 0.8$ нТл. У першому інтервалі часу переважали коливання з пе- ріодом $T \approx 400 \div 1000$ с, а в другому інтервалі часу - коливання 3 періодом $T \approx 600 \div 900 \mathrm{c}$.

У день землетрусу до 19:00 амплітуда флуктуацій $H$-компоненти не перевищувала 0.3 нТл (рис. 3). 3 18:00 до 18:20 спостерігався двополярний імпульс: спочатку рівень $H$-компоненти збільшився від 0 до 0.3 нТл, потім зменшився від 0.3 до -0.3 нТл, після чого знову збільшився від -0.3 до 0.3 нТл 3 подальшим зменшенням до 0 нТл. Квазіперіод склав близько 13 хв. 3 19:40 і до 20:25 мало місце збільшення рівня $H$-компоненти до 0.8 нТл, а в інтервалі часу 3 19:39 до 19:45 - навіть до 1.8 нТл. Водночас спостерігалися коливання 3 періодами близько 120 і $700 \div 900$ с. В інтервалі часу 19:10-20:30 на коливання 3 періодом $T \approx 13 \div 14$ хв наклалося більш високочастотне коливання. Рівень $D$-компоненти флуктуював у межах $\pm(0.2 \div 0.3)$ нТл. В інтервалі часу 19:10-20:50 характер варіацій змінився.

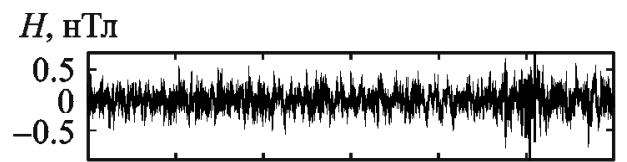

$T$, c 1000
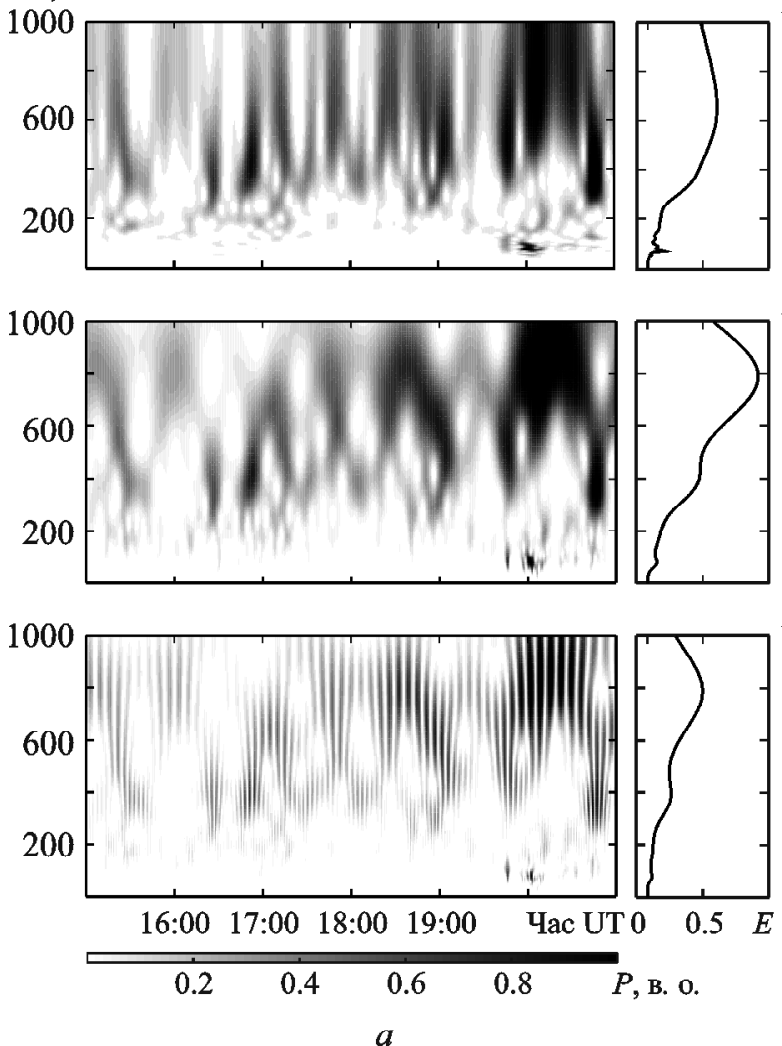

$D$, нТл

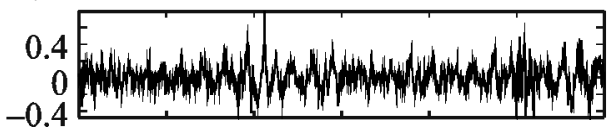

$T, \mathrm{c}$

1000
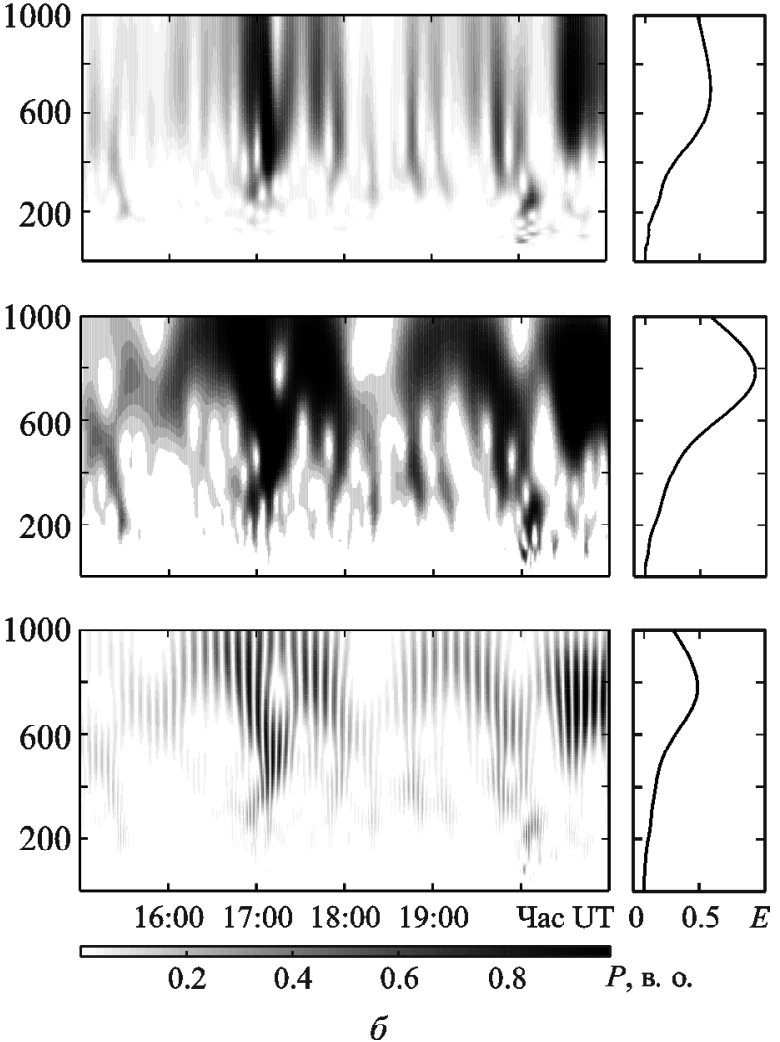

Puc. 2. Часові варіації та результати ВПФ, АПФ та ВП (панелі зверху вниз) горизонтальних $H$-компоненти (a) та $D$-компоненти (б) геомагнітного поля в діапазоні періодів $1 \div 1000$ с 23 січня 2020 р. Справа показано енергограми (розподіл відносної енергії коливань за періодами) 
$H$, нТл

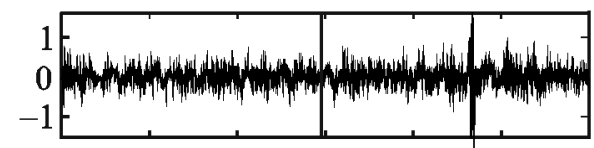

$T, \mathrm{c}$
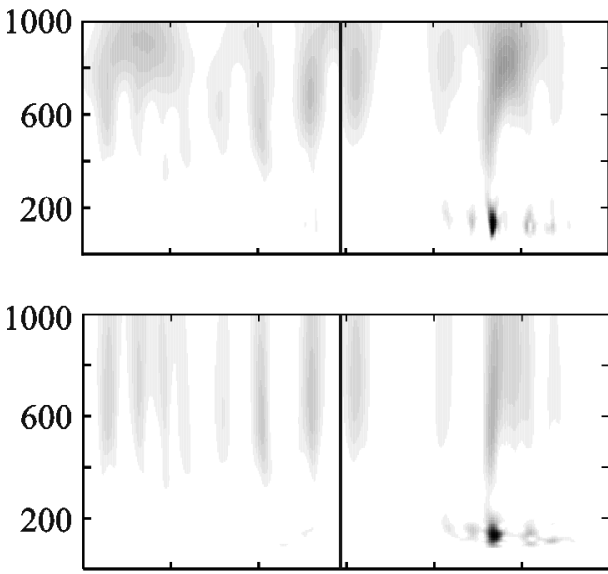

1000

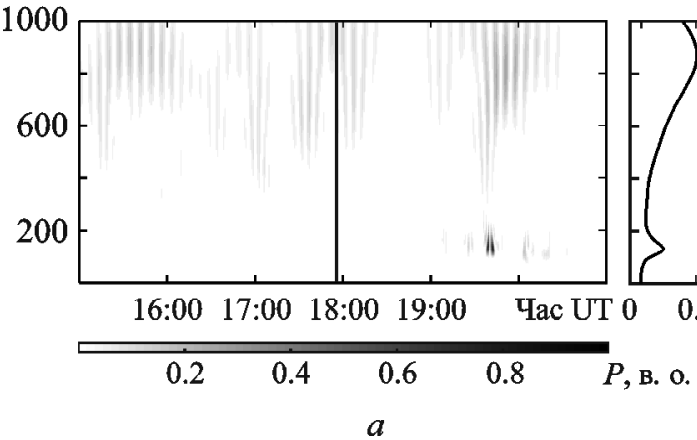

$D$, нТл

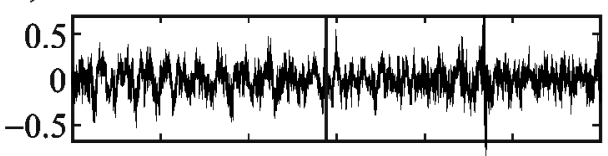

$T, \mathrm{c}$
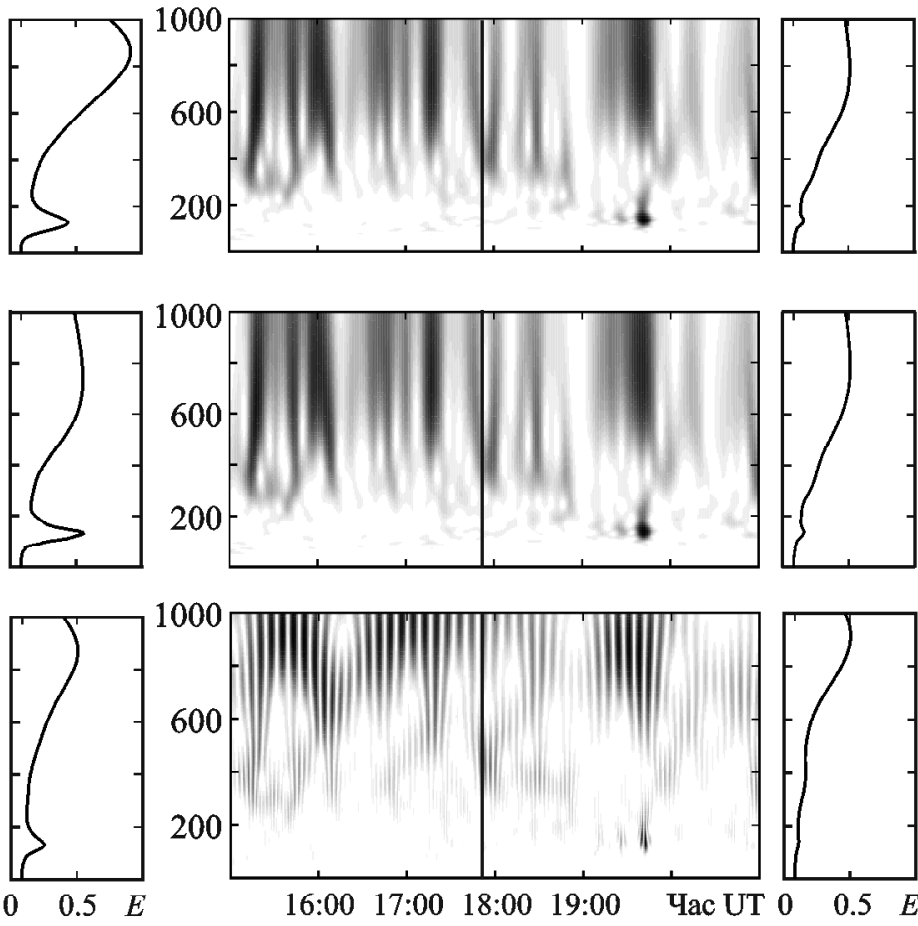

1000
600
200
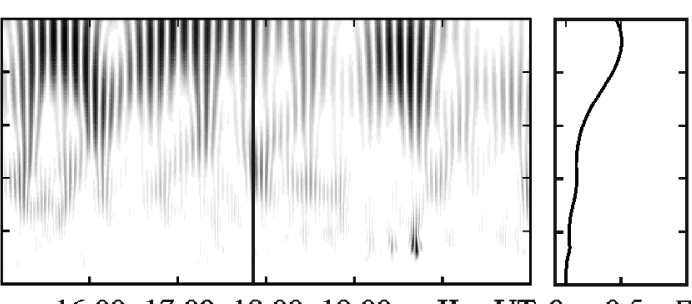

$\begin{array}{lllllll}16: 00 & 17: 00 & 18: 00 & 19: 00 & \text { Чac UT } 0 & 0.5 & E\end{array}$

0.2

6

Puc. 3. Те ж, що і на рис. 2 для 24 січня 2020 р. Вертикальною лінією показано момент землетрусу

3 19:39 до 19:45 мало місце різке збільшення амплітуди до $\approx 0.75$ нТл. У цьому інтервалі часу з'явилося коливання з періодом $T \approx 120$ с. На коливання 3 періодом $T \approx 14$ хв наклалося більш високочастотне коливання.

Поведінка $H$ i $D$ компонент геомагнітного поля 25 січня 2020 р. була наступною (рис. 4). В інтервалах часу 15:30-16:10, 16:50-17:30 та 19:35-20:10 мало місце збільшення рівня $H$-компоненти до $0.3 \div 0.4$ нТл. В інших інтервалах часу амплітуда не перевищувала 0.2 нТл. Рівень $D$-компоненти флуктуював у межах $0.20 \div 0.25$ нТл. Для обох компонент період переважаючих коливань становив $700 \div 900$ с.

\section{6. Обговорення}

Збільшення рівнів $H$ і $D$ компонент геомагнітного поля 23 січня 2020 р. в інтервалі часу 19:40-21:00 пов'язане $з$ посиленням магнітної активності. При- близно в той же час відбувалося збільшення до $1.3 K_{p}$-індексу та зменшення до -10 нТл $D_{s t}$ індексу (див. рис. 1). Збільшення рівня флуктуацій $D$-компоненти з 16:30 до 18:00 не пов'язане з підсиленням магнітної активності. У той час $K_{p} \approx 0.3$, a $D_{s t} \approx-5$ нТл. Зазначене збільшення могло бути пов'язане з передвісником землетрусу. Амплітуда та період коливань відповідають параметрам передвісника, викликаного механізмом, описаним у роботі [33].

24 січня 2020 р. двохполярний імпульс у варіаціях $H$-компоненти міг бути викликаний землетрусом. Якщо це так, то час запізнення імпульсу після сейсмічного удару становив $\Delta t_{0} \approx 5$ хв. Саме такий час потрібен для досягнення висоти $z \sim 100$ км знакозмінним імпульсом тиску атмосферного газу, згенерованим подібним до руху поршня рухом поверхні грунту при землетрусі. Імпульс тиску, в свою чергу, згенерував на висотах дина- 
$H$, нТл

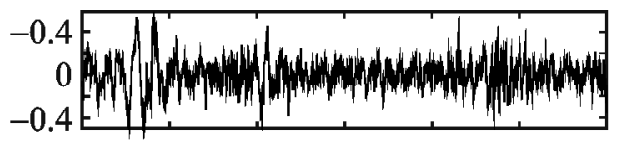

$T, \mathrm{c}$

1000
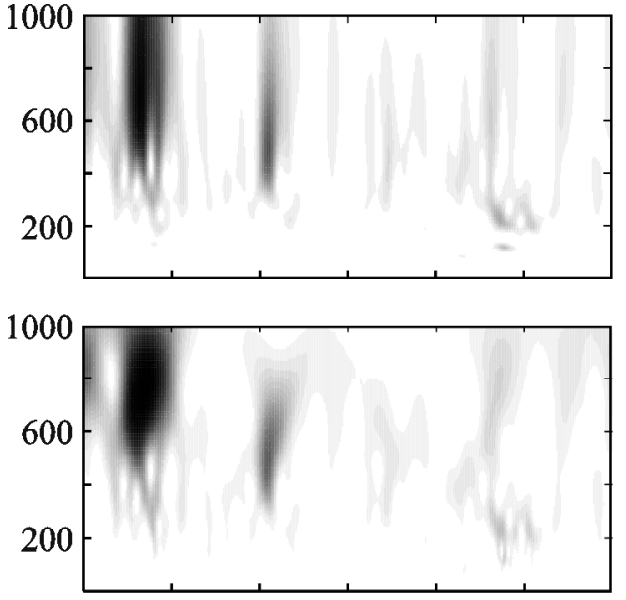

1000

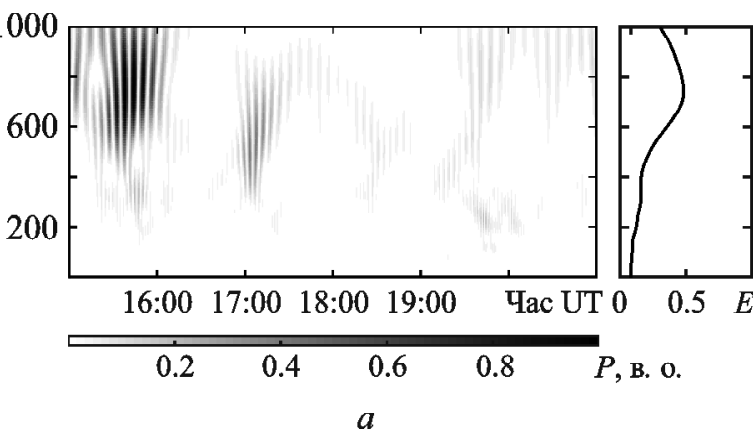

Puc. 4. Те ж, що і на рис. 2 для 25 січня 2020 p.

мо-області атмосфери ( $z \sim 100$ км) знакозмінний МГД імпульс, зареєстрований магнітометром. Швидкість МГД хвиль в іоносфері згідно роботи [32] є близькою до 20 км/с. Тоді час поширення від епіцентру до місця спостереження становить близько 1 хв, що набагато менше значення $\Delta t_{0}$.

Зміна характеру поведінки обох компонент спостерігалася о 19:10. Передбачуваний час запізнення становить $\Delta t_{1} \approx 75$ хв. Оцінимо вдавану горизонтальну швидкість поширення збурень за формулою

$$
v=\frac{R}{\Delta t_{1}-\Delta t_{0}}
$$

де $R \approx 1350$ км - відстань між магнітометром $\mathrm{i}$ епіцентром землетрусу, $\Delta t_{0} \approx 5 \mathrm{xв}-$ час поширення збурення від епіцентру до висоти динамо-області атмосфери. Оцінка за співвідношенням (1)
$D$, нТл

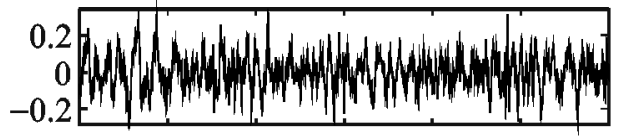

$T, \mathrm{c}$ 1000
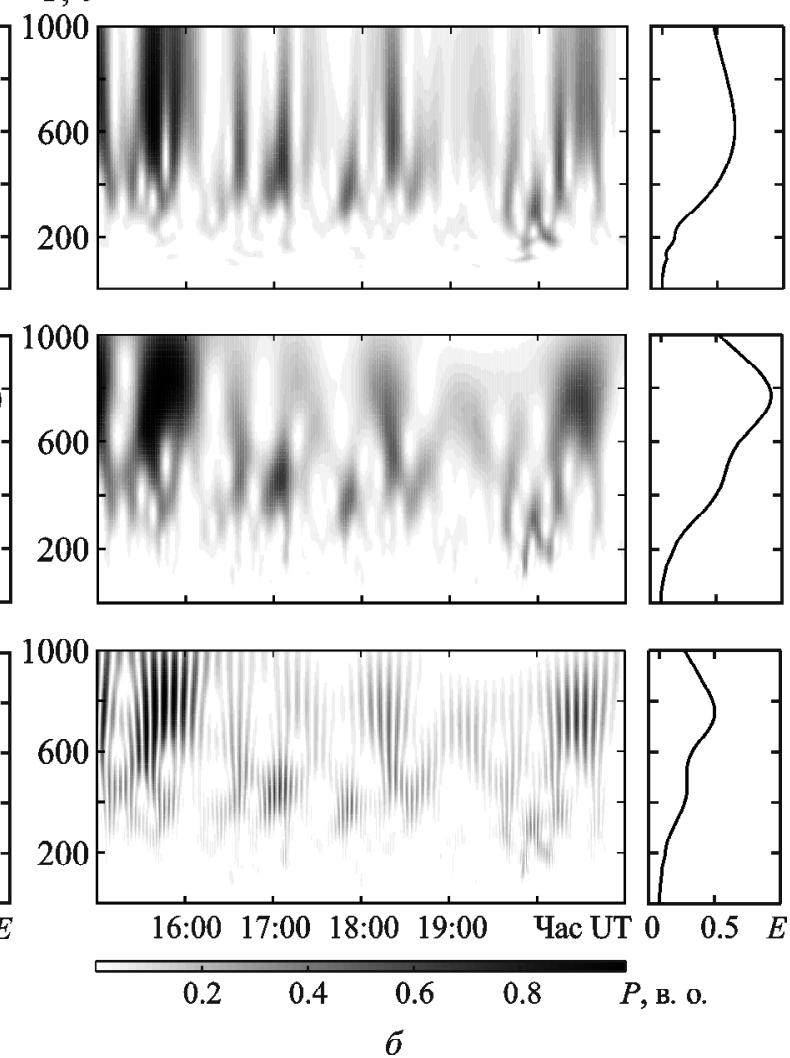

дає $v \approx 320 \mathrm{~m} / \mathrm{c}$. Таку швидкість і період $T \approx 12 \div 15$ хв мають АГХ.

Механізм генерації магнітного ефекту уявляється наступним. Згенерована землетрусом АГХ поширюється від епіцентру, досягаючи висот іоносферного струму у динамо-області атмосфери, модулює концентрації нейтральних частинок і електронів, густину іоносферного струму, генерує збурення геомагнітного поля $\Delta B$, яке реєструється магнітометром.

3 роторного рівняння Максвела

$\operatorname{rot} \mathbf{B}=\mu_{0} \mathbf{j}$

випливає оцінка

$\Delta B=\mu_{0} \Delta j \Delta z$,

де $\mu_{0}=4 \pi \cdot 10^{-7} \Gamma \mathrm{H} / \mathrm{M}-$ магнітна стала, $\mathbf{j}$ - густина іоносферного струму, $\Delta j$ - його збурення, 
$\Delta z \approx 30$ км - товщина динамо-області атмосфери. АГХ модулює концентрацію електронів $N$ з періодом $T$. За відносної амплітуди $\delta_{N}=\left(N-N_{0}\right) / N_{0}$, де $N_{0}$ - незбурене значення $N$, збурення густини іоносферного струму $\Delta j=j_{0} \delta_{N}$. Тут $j_{0}$ - густина незбуреного іоносферного струму. Тоді співвідношення (2) перепишеться так:

$\Delta B=\mu_{0} j_{0} \delta_{N} \Delta z$.

При значеннях $j_{0} \approx 10^{-7} \mathrm{~A} / \mathrm{M}^{2}$ в нічний час, $\Delta z \approx 30$ км і $\Delta B \approx 0.3$ нТл з (3) маємо $\delta_{N} \approx 8 \%$. Подібне значення $\delta_{N}$, як і період $T \approx 12 \div 15$ хв властиві рухомим іоносферним збуренням, викликаним АГХ.

Окремо зупинимося на варіаціях обох компонент 24 січня 2020 р. в інтервалі часу 19:39-19:45 (рис. 5). 3 рис. 5 видно, що мають місце загасаючі коливання з періодом близьким до 120 с. Такий період властивий атмосферному інфразвуку. Характер варіацій свідчить про те, що мав місце ударний вплив на атмосферу. Внаслідок цього згенерувалася ударна хвиля, яка поширювалася на всі боки від епіцентру уздовж хвилеводу Землятермосфера. Вона призвела до модуляції концентрації електронів і густини іоносферного струму.

Це послужило причиною спостережуваних геомагнітних варіацій. Якщо ударна хвиля згенерована землетрусом, то при $\Delta t_{2} \approx 104$ хв маємо вдавану горизонтальну швидкість поширення збурення $v_{2} \approx 230 \mathrm{~m} / \mathrm{c}$. Таку швидкість має інфраз-
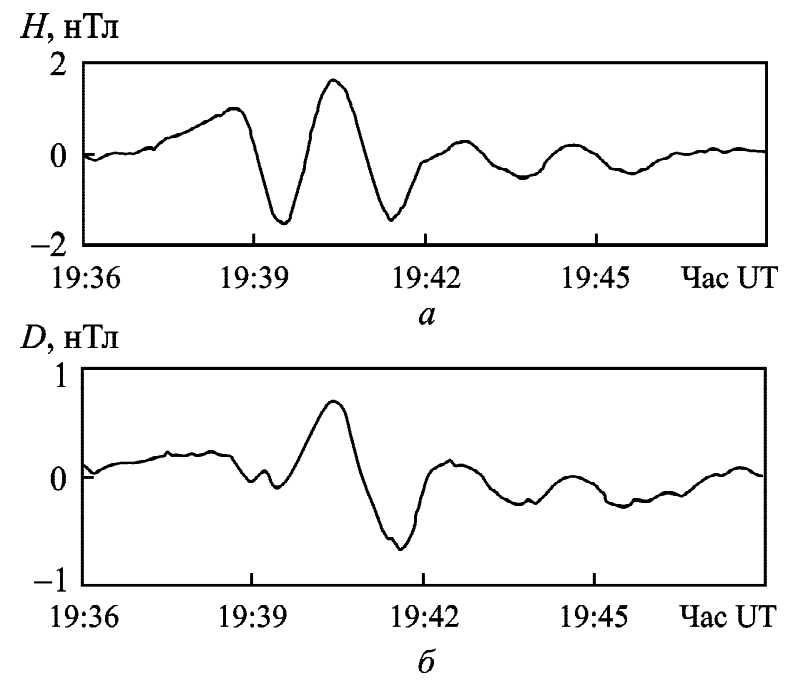

Puc. 5. Часові варіації горизонтальних $H$-компоненти (a) та $D$-компоненти (б) геомагнітного поля в діапазоні періодів $1 \div 1000$ с 24 січня 2020 р. в інтервалі часу 19:36-19:48 вук, який поширюється в хвилеводі Земля-термосфера $[73,74]$. За такої умови інфразвукова хвиля відбивається на висотах термосфери, тобто там, де густина іоносферного струму сягає максимального значення.

\section{7. Основні результати}

1. Спостережуваний 23 січня 2020 р. приблизно за 25.5 год до землетруса цуг коливань у рівні $D$-компоненти геомагнітного поля міг бути пов'язаний 3 магнітним передвісником.

2. Двополярний імпульс у $H$-компоненті геомагнітного поля 24 січня 2020 р. міг бути зумовлений поршневим впливом землетрусу, що згенерував МГД імпульс.

3. Квазіперіодичні варіації рівня $H$ і $D$ компонент геомагнітного поля, що спостерігалися через 75 хв після землетрусу, були викликані генерацією магнітного збурення рухомими іоносферними збуреннями, зумовленими АГХ від землетрусу. Амплітуда магнітного ефекта була близькою до 0.3 нТл, квазіперіод - до $700 \div 900$ c.

4. За оцінками відносна амплітуда збурень концентрації електронів у полі АГХ становила близько $8 \%$, а період - $700 \div 900$ с.

5 . Виявлено загасаючі коливання в обох компонентах магнітного поля з періодом близько $120 \mathrm{c}$. Припускаєься, що ефект пов' язаний з генерацією ударної хвилі в атмосфері під час землетрусу.

Робота Л. Ф. Чорногора та К. П. Гармаша фінансувалася в рамках держбюджетної НДР установ МОН України, номер держреєстрації $0119 U 002538$. Робота Y. Luo та Л. Ф. Чорногора виконана також за фінансової підтримки Національного фонду досліджень України, проєкт 2020.02/0015 “Теоретичні та експериментальні дослідження глобальних збурень природного і техногенного походження в системі Земля - атмосфера - іоносфера".

\section{СПИСОК ЛІТЕРАТУРИ}

1. Пудовкин М. И., Распопов О. М., Клейменова Н. Г. Возмущения электромагнитного поля Земли. Ч. 2. Ленинград: Изд-во ЛГУ, 1976. 270 с.

2. Гульельми А. В. МГД-волны в околоземной плазме. Москва: Наука, 1979. 139 с.

3. Нишида А. Геомагнитный диагноз магнитосферы. Москва: Мир, 1980. 299 с.

4. Гульельми А. В., Троицкая В. А. Геомагнитные пульсации и диагностика магнитосферы. Москва: Наука, 1973. $208 \mathrm{c}$. 
5. Лихтер Я. И., Гульельми А. В., Ерухимов Л. М., Михайлова Г. А. Волновая диагностика приземной плазмы. Москва: Наука, 1988. 215 с.

6. Черногор Л. Ф. Геомагнитные пульсации, сопутствовавшие движению солнечного терминатора через магнитосопряженную область. Радиофизика и радиоастрономия. 2012. Т. 17, № 1. С. 57-66.

7. Черногор Л. Ф. Крупномасштабные возмущения магнитного поля Земли, сопровождавшие падение Челябинского метеороида. Радиофизика и электроника. 2013. T. 4 (18), № 3. C. 47-54.

8. Черногор Л. Ф. Эффекты Челябинского метеороида в геомагнитном поле. Геомагнетизм и аэрономия. 2014. T. 54, № 5. C. 658-669.

9. Черногор Л. Ф. Эффекты в магнитосфере при подлете Челябинского метеороида. Геомагнетизм и аэрономия. 2018. T. 58, № 2. C. 267-280.

10. Блиох П. В., Николаенко А. П., Филиппов Ю. Ф. Глобальные электромагнитные резонансы в полости Земля - ионосфера. Киев: Наукова думка, 1977. 181 с.

11. Чекрыжов В. М., Свиркунов П. Н., Козлов С. В. Влияние циклонической активности на возмущение геомагнитного поля. Геомагнетизм и аэрономия. 2019. T. 59, № 1. C. 59-68.

12. Мартинес-Беденко В. А., Пилипенко В. А., Захаров В. И., Грушин В. А. Влияние тайфуна Vongfong 2014 г. на ионосферу и геомагнитное поле по данным спутников Swarm: 2. Геомагнитные возмущения. Солнечно-земная физика. 2019. Т. 5, № 4. С. 90-98.

13. Current research in Earth prediction. T. Rikitake, ed. Dordrecht: D. Reidel Publishing, 1981. 510 p.

14. Гохберг М. Б., Моргунов В. А., Похотелов О. А. Сейсмоэлектромагнитные явления. Москва: Наука, 1988. $180 \mathrm{c}$.

15. Electromagnetic Phenomena Related to Earthquake Prediction. M. Hayakawa and Y. Fujinawa, eds. Tokyo: TERRAPUB, 1994. $677 \mathrm{p}$.

16. Atmospheric and Ionospheric Electromagnetic Phenomena Associated with Earthquakes. M. Hayakawa, ed. Tokyo: TERRAPUB, 1999. 996 p.

17. Сурков В. В. Электромагнитные эффекты при взрывах и землетрясениях. Москва: МИФИ, 2000. 448 с.

18. Seismo Electromagnetics: Lithosphere-AtmosphereIonosphere Coupling. M. Hayakawa and O. A. Molchanov, eds. Tokyo: TERRAPUB, 2002. $477 \mathrm{p}$.

19. Соболев Г. А., Пономарёв А. В. Физика землетрясений и предвестников. Москва: Наука, 2003. 270 с.

20. Molchanov O. A. and Hayakawa M. Seismo-Electromagnetics and Related Phenomena: History and Latest Results. Tokyo: TERRAPUB, 2008. 198 p.

21. Electromagnetic phenomena associated with earthquakes. M. Hayakawa, ed. Trivandrum, India: Transworld Research Network, 2009. 279 p.

22. Earthquakes Prediction Studies: Seismo Electromagnetic. M. Hayakawa, ed. Tokyo: TERRAPUB, 2013. 794 p.

23. Surkov V. and Hayakawa M. Ultra and Extremely Low Frequency Electromagnetic Fields. Tokyo, Heidelberg, New York, Dordrecht, London: Springer Japan, 2014. 486 p.

24. Гохберг М. Б., Шалимов С. Л. Воздействие землетрясений и взрывов на ионосферу. Москва: Наука, 2008. $295 \mathrm{c}$.
25. Черногор Л. Ф. Физика и экология катастроф. Харьков: ХНУ имени В. Н. Каразина, 2012.

26. Черногор Л. Ф., Гармаш К. П. Магнито-ионосферные эффекты, сопровождавшие сильнейшую техногенную катастрофу. Геомагнетизм и аэрономия. 2018. Т. 58, № 5. C. 700-712.

27. Черногор Л. Ф. Радиофизические и геомагнитные эффекты стартов ракет: Монография. Харьков: ХНУ имени В. Н. Каразина, 2009. 386 с.

28. Chernogor L. F. and Blaunstein N. Radiophysical and Geomagnetic Effects of Rocket Burn and Launch in the Nearthe-Earth Environment. Boca Raton, London, New York: CRC Press. Taylor \& Francis Group, 2013. 542 p.

29. Черногор Л. Ф. О возможном воздействии запусков ракетно-космической техники на магнитное поле Земли. Воздействие ракетно-космической техники на окружсающую природную среду. Под ред. В. В. Адушкина, С. И. Козлова, М. В. Сильникова. Москва: ГЕОС, 2016. $795 \mathrm{c}$.

30. Черногор Л. Ф., Вертоградов Г. Г., Урядов В. П., Вертоградова Е. Г., Шамота М. А. Согласованные квазипериодические вариации уровня геомагнитных пульсаций и доплеровского смещения частоты ракурсно-рассеянных искусственными ионосферными неоднородностями радиоволн декаметрового диапазона. Изв. вузов. Радиофизика. 2010. Т. 53, № 12. С. 766-785.

31. Черногор Л. Ф. Физика мощчного радиоизлучения в геокосмосе: монография. Харьков: ХНУ имени В. Н. Каразина, 2014. $448 \mathrm{c}$.

32. Черногор Л. Ф. Геомагнитные возмущения, сопровождавшие Великое японское землетрясение 11 марта 2011 г. Геомагнетизм и аэрономия. 2019. Т. 59, № 1. C. 69-82.

33. Черногор Л. Ф. Возможность генерации квазипериодических магнитных предвестников землетрясений. Геомагнетизм и аэрономия. 2019. Т. 59, № 3. C. $400-408$.

34. Черногор Л. Ф. Физика Земли, атмосферы и геокосмоса в свете системной парадигмы. Радиофизика и радиоастрономия. 2003. Т. 8, № 1. С. 59-106.

35. Черногор Л. Ф. Земля - атмосфера - ионосфера - магнитосфера как открытая динамическая нелинейная физическая система. 1. Нелинейный мир. 2006. Т. 4, № 12. C. $655-697$.

36. Черногор Л. Ф. Земля - атмосфера - ионосфера - магнитосфера как открытая динамическая нелинейная физическая система. 2. Нелинейный мир. 2007. Т. 5, № 4. C. 198-231.

37. Chernogor L. F. and Rozumenko V. T. Earth - Atmosphere - Geospace as an Open Nonlinear Dynamical System. Radio Phys. Radio Astron. 2008. Vol. 13, No. 2. P. $120-137$.

38. Chernogor L. F. The Earth-atmosphere-geospace system: main properties and processes. Int. J. Remote Sens. 2011. Vol. 32, No. 11. P. 3199-3218. DOI: 10.1080/01431161. 2010.541510

39. Guo Q., Chernogor L. F., Garmash K. P., Rozumenko V. T., and Zheng Y. Dynamical processes in the ionosphere following the moderate earthquake in Japan on 7 July 2018. J. Atmos. Sol.-Terr. Phys. 2019. Vol. 186. P. 88-103. DOI: 10.1016/j.jastp.2019.02.003 
40. Luo Y., Guo Q., Zheng Yu., Гармаш К. П., Черногор Л. Ф., Шульга С. Н. Варіації характеристик радіохвиль ВЧ діапазону над Китаєм, які супроводжували помірний землетрус в Японії 5 вересня 2018 р. Вісник Харківського національного університету імені В. Н. Каразіна. Радіофізика та електроніка. 2019. Вып. 30. С. 16-26. DOI: 10.26565/2311-0872-2019-30-02

41. Luo Y., Гармаш К. П., Черногор Л. Ф., Шульга С. Н. Флуктуации геомагнитного поля, сопровождавшие Чуйские землетрясения в сентябре-октябре 2003 г. Вісник Харківського національного університету імені В. Н. Каразіна. Радіофізика та електроніка. 2019. Вып. 31. C. 87-104. DOI: 10.26565/2311-0872-2019-31-09

42. Luo Y., Чорногор Л. Ф., Гармаш К. П., Guo Q., Zheng Yu. Сейсмо-іоносферні ефекти: результати похилого радіозондування іоносфери. Радіофізика і радіоастрономія. 2020. Т. 25, № 3. C. 218-230. DOI: $10.15407 /$ rpra25.03.218

43. Moore G. W. Magnetic Disturbances preceding the 1964 Alaska Earthquake. Nature. 1964. Vol. 203. P. 508-509. DOI: $10.1038 / 203508$ b0

44. Воробьев А. А. О возможности электрических разрядов в недрах Земли. Геология и геофизика. 1970. № 12. С. 3-13.

45. Гогатишвили Я. М. Геомагнитные предвестники интенсивных землетрясений в спектре геомагнитных пульсаций с частотами 1-0.02 Гц. Геомагнетизм и аэрономия. 1984. Т. 24, № 4. С. 697-700.

46. Сидорин А. Я. Предвестники землетрясений. Москва: Наука, 1992. 162 с.

47. Собисевич Л. Е., Канониди К. Х., Собисевич А. Л. Ультранизкочастотные электромагнитные возмущения, возникающие перед сильными сейсмическими событиями. Доклады Академии наук. 2009. Т. 429, № 5. С. 668-672.

48. Собисевич Л. Е., Собисевич А. Л., Канониди К. Х. Аномальные геомагнитные возмущения, наведенные катастрофическими цунамическими землетрясениями в районе Индонезии. Геофизический журнал. 2012. T. 34, №5. C. 22-37. DOI: 10.24028/gzh.02033100.v34i5.2012.116661

49. Собисевич Л. Е., Канониди К. Х., Собисевич А. Л., Мисеюк О. И. Геомагнитные возмущения в вариациях магнитного поля Земли на этапах подготовки и развития Турецкого (08.03.2010 г.) и Северокавказского (19.01.2011 г.) землетрясений. Доклады Академии наук. 2013. Т. 449, № 1. С. 93-96.

50. Собисевич А. Л., Старостенко В. И., Собисевич Л. Е., Кендзера А. В., Шуман В. Н., Вольфман Ю. М., Потемка Э. П., Канониди К. Х., Гарифулин В. А. Черноморские землетрясения конца декабря 2012 г. и их проявления в геомагнитном поле. Геофизический журнал. 2013. Т. 35, № 6. С. 54-70. DOI: $10.24028 /$ gzh.0203-3100.v35i6.2013.116455

51. Собисевич Л. Е., Собисевич А. Л., Канониди К. Х. О некоторых аномальных процессах в геосферах при подготовке и развитии сейсмических событий. Триггерные эффекты в геосферах. Материаль третьего Всероссийского семинара-совещания. Под ред. В. В. Адушкина, Г. Г. Кочаряна. Москва: ГЕОС, 2015. С. 284-294.

52. Fraser-Smith A. C., Bernardi A., McGill P. R., Ladd M. E., Halliwell R. A., and Willard O. G., Jr. Low-frequency mag- netic field measurements near the epicenter of the $\mathrm{M}_{\mathrm{s}}=7.1$ Loma Prieta Earthquake. Geophys. Res. Lett. 1990. Vol. 17, Is. 9. P. 1465-1468. DOI: 10.1029/GL017i009p01465

53. Campbell W. H. Natural magnetic disturbance fields, not precursors, preceding the Loma Prieta earthquake. J. Geophys. Res. Spase Phys. 2009. Vol. 114, Is. A5. id. A05307. DOI: $10.1029 / 2008$ JA013932

54. Шестопалов И. П., Белов С. В., Соловьев А. А., Кузьмин Ю. Д. О генерации нейтронов и геомагнитных возмущениях в связи с Чилийским землетрясением 27 февраля и вулканическим извержением в Исландии в марте-апреле 2010 г. Геомагнетизм и аэрономия. 2013. Т. 53, № 1. C. $130-142$. DOI: $10.7868 / \mathrm{S} 0016794013010185$

55. Романова Н. В., Пилипенко В. А., Степанова М. В. О магнитном предвестнике Чилийского землетрясения 27 февраля 2010 г. Геомагнетизм и аэрономия. 2015. T. 55, № 2. C. 231-234. DOI: 10.7868/S0016794015010101

56. Molchanov O. A., Kopytenko Yu. A., Voronov P. M., Kopytenko E. A., Matiashvili T. G., Fraser-Smith A. C., and Bernardi A. Results of ULF magnetic field measurements near the epicenters of the Spitak $\left(\mathrm{M}_{s}=6.9\right)$ and the Loma Prieta $(\mathrm{M}=7.1)$ earthquakes: Comparative analysis. Geophys. Res. Lett. 1992. Vol. 19, Is. 14. P. 1495-1498. DOI: $10.1029 / 92$ GL01152

57. Kopytenko Yu. A., Matiashvili T. G., Voronov P. M., Kopytenko E. A., and Molchanov O. A. Detection of ultralow-frequency emissions connected with the Spitak earthquake and its aftershock activity, based on geomagnetic pulsations data at Dusheti and Vardzia observatories. Phys. Earth Planet. Inter. 1993. Vol. 77, Is. 1-2. P. 85-95. DOI: 10.1016/0031-9201(93)90035-8

58. Hayakawa M., Kawate R., Molchanov O. A., and Jumoto K. Results of ultra-low-frequency magnetic field measurements during the Guam earthquake of 8 August 1993. Geophys. Res. Lett. 1996. Vol. 23, Is. 3. P. 241-244. DOI: 10.1029/95GL02863

59. Schekotov A., Fedorov E., Hobara Y., and Hayakawa M. ULF Magnetic Field Depression as a Possible Precursor to the 2011/3.11 Japan Earthquake. J. Atmos. Electr. 2013. Vol. 33, Is. 1. P. 41-51. DOI: 10.1541/jae.33.41

60. Schekotov A., Fedorov E., Hobara Y., and Hayakawa M. ULF magnetic field depression as a possible precursor to the 2011/3.11 Japan earthquake. Радиофизика и электроника. 2013. Т. 4(18), № 1. C. 47-52.

61. Fraser-Smith A. C., McGill P. R., Helliwell R. A., and Villard O. G., Jr. Ultra-low frequency magnetic field measurements in southern California during the Northridge Earthquake of 17 January 1994. Geophys. Res. Lett. 1994. Vol. 21, Is. 20. P. 2195-2198. DOI: 10.1029/94GL01984

62. Karakelian D., Klemperer S. L., Fraser-Smith A. C., and Thompson G. A. Ultra-low frequency electromagnetic measurements associated with the $1998 \mathrm{M}_{w}$ 5.1 San Juan Bautista, California earthquake and implications for mechanisms of electromagnetic earthquake precursors. Tectonophysics. 2002. Vol. 359, Is. 1-2. P. 65-79. DOI: 10.1016/ S0040-1951(02)00439-0

63. Fraser-Smith A. C. Ultralow-Frequency Magnetic Fields Preceding Large Earthquakes. Eos. 2008. Vol. 89, No. 23. P. 211. DOI: 10.1029/2008EO230007

64. Park S. K., Johnson M. J. S., Madden T. R., Morgan F. D., and Morrison H. F. Electromagnetic precursors to earth- 
quakes in the ULF band: A review of observations and mechanisms. Rev. Geophys. 1993. Vol. 31, Is. 2. P. 117-132. DOI: $10.1029 / 93 R G 00820$

65. Geller R. J. Earthquake prediction: a critical review. Geophys. J. Int. 1997. Vol. 131, Is. 3. P. 425-450. DOI: 10.1111/ j.1365-246X.1997.tb06588.x

66. Bakun W. H., Aagaard B., Dost B., Ellsworth W. L., Hardebeck J. L., Harris R. A., Ji C., Johnston M. J. S., Langbein J., Lienkaemper J. J., Michael A. J., Murray, J. R., Nadeau R. M., Reasenberg P. A., Reichle M. S., Roeloffs E. A., Shakal A., Simpson R. W., and Waldhauser F. Implications for prediction and hazard assessment from the 2004 Parkfield earthquake. Nature. 2005. Vol. 437. P. 969-974. DOI: 10.1038/nature04067

67. Костерин Н. А., Пилипенко В. А., Дмитриев Э. М. О глобальных ультранизкочастотных электромагнитных сигналах перед землетрясениями. Геофизические исследования. 2015. Т. 16, № 1. С. 24-34.

68. Бахмутов В. Г., Седова Ф. И., Мозговая Т. А. Морфологические признаки в структуре геомагнитных вариаций в период подготовки сильнейшего землетрясения 25 марта 1998 г. в Антарктиде. Український антарктичний журнал. 2003. № 1. С. 54-60.

69. Surkov V. V. and Pilipenko V. A. Magnetic effects due to earthquakes and underground explosions: a review. Ann. Geophys. 1997. Vol. 40, No. 2. P. 227-239. DOI: 10.4401/ ag-3904

70. Гульельми А. В. Ультранизкочастотные электромагнитные волны в коре и в магнитосфере Земли. УФН. 2007. T. 177, № 12. C. 1250-1276. DOI: 10.3367/UFNr.0177. 200712a.1257

71. Пулинец С. А., Узунов Д. П., Карелин А. В., Давиденко Д. В. Физические основы генерации краткосрочных предвестников землетрясений. Комплексная модель геофизических процессов в системе литосфера - атмосфера - ионосфера - магнитосфера, инициируемых ионизацией. Геомагнетизм и аэрономия. 2015. Т. 55, № 4. C. 540-558. DOI: 10.7868/S0016794015040136

72. Черногор Л. Ф. Современные методы спектрального анализа квазипериодических и волновых процессов в ионосфере: особенности и результаты экспериментов. Геомагнетизм и аэрономия. 2008. Т. 48, № 5. С. 681-702.

73. Куличков С. Н. Дальнее распространение звука в атмосфере (Обзор). Известия РАН. Физика атмосферы и океана. 1992. Т. 28, № 4. С. 339-360.

74. Infrasound monitoring for atmospheric studies. A. Le Pichon, E. Blanc, and A. Hauchecorne, eds. Dordrecht, Heidelberg, London, New York: Springer Int. Publ., 2010. 1167 p. DOI: $10.1007 / 978-1-4020-9508-5$

\section{REFERENCES}

1. PUDOVKIN, M. I., RASPOPOV, O. M. and KLEIMENOVA, N. G., 1976. Disturbances of the Earth's Electromagnetic Field. vol. 2. Leningrad, Russia: LGU Publ. (in Russian).

2. GUGLIELMI, A. V., 1979. MHD Waves in Near-Earth Plasma. Moscow, Russia: Nauka Publ. (in Russian).

3. NISHIDA, A., 1980. Geomagnetic Diagnosis of the Magnetosphere. Moscow, Russia: Mir Publ. (in Russian).
4. GUGLIELMI, A. V. and TROITSKAYA, V. A., 1973. Geomagnetic Pulsations and Diagnostics of the Magnetosphere. Moscow, Russia: Nauka Publ. (in Russian).

5. LIKHTER, YA. I., GUGLIELMI, A. V., ERUKHIMOV, L. M. and MIKHAILOVA, G. A., 1988. Wave Diagnostics of Surface Plasma. Moscow, Russia: Nauka Publ. (in Russian).

6. CHERNOGOR, L. F., 2012. Geomagnetic Pulsations Accompanied the Solar Terminator Moving Through Magnetoconjugate Region. Radio Phys. Radio Astron. vol. 17, no. 1, pp. 57-66. (in Russian).

7. CHERNOGOR, L. F., 2013. Large-Scale Disturbances in the Earth's Magnetic Field Associated with the Chelyabinsk Meteorite Event. Radiofiz. Electron. vol. 4 (18), no. 3, pp. 47-54. (in Russian).

8. CHERNOGOR, L. F., 2014. Geomagnetic field effects of the Chelyabinsk meteoroid. Geomagn. Aeron. vol. 54, is. 5, pp. 613-624. DOI: 10.1134/S001679321405003X

9. CHERNOGOR, L. F., 2018. Magnetospheric Effects during the Approach of the Chelyabinsk Meteoroid. Geomagn. Aeron. vol. 58, is. 2, pp. 252-265. DOI: 10.1134/ S0016793218020044

10. BLIOKH, P. V., NIKOLAENKO, A. P. and FILIPPOV, YU. F., 1977. Global Electromagnetic Resonances in the Earth-Ionosphere Cavity. Kiev: Naukova dumka Publ. (in Russian).

11. CHEKRYZHOV, V. M., SVIRKUNOV, P. N. and KOZLOV, S. V., 2019. The Influence of Cyclonic Activity on the Geomagnetic Field Disturbance. Geomagn. Aeron. vol. 59, is. 1, pp. 53-61. DOI: $10.1134 / \mathrm{S} 0016793$ 219010031

12. MARTINES-BEDENKO, V. A., PILIPENKO, V. A., ZAKHAROV, V. I. and GRUSHIN, V. A., 2019. Influence of the Vongfong 2014 hurricane on the ionosphere and geomagnetic field as detected by Swarm satellites: 2. Geomagnetic disturbances. Sol.-Terr. Phys. vol. 5, is. 4, pp. 74-80. DOI: $10.12737 / \mathrm{stp}-54201910$

13. RIKITAKE, T., ed., 1981. Current research in Earth prediction. Dordrecht: D. Reidel Publishing.

14. GOKHBERG, M. B., MORGUNOV, V. A. and POKHOTELOV, O. A., 1988. Seismoelectromagnetic Phenomena. Moscow, Russia: Nauka Publ. (in Russian).

15. HAYAKAWA, M. and FUJINAWA, Y., eds., 1994. Electromagnetic Phenomena Related to Earthquake Prediction. Tokyo: TERRAPUB.

16. HAYAKAWA, M., ed., 1999. Atmospheric and Ionospheric Electromagnetic Phenomena Associated with Earthquakes. Tokyo: TERRAPUB.

17. SURKOV, V. V., 2000. Electromagnetic Effects Caused by Explosions and Earthquakes. Moscow, Russia: MIFI Publ. (in Russian).

18. HAYAKAWA, M. and MOLCHANOV, O. A., eds., 2002. Seismo Electromagnetics: Lithosphere-Atmosphere-Ionosphere Coupling. Tokyo: TERRAPUB.

19. SOBOlEV, G. A. and PONOMAREV, A. V., 2003. Physics of Earthquakes and Precursors. Moscow, Russia: Nauka Publ. (in Russian).

20. MOLCHANOV, O. A. and HAYAKAWA, M., 2008. Seismo-Electromagnetics and Related Phenomena: History and Latest Results. Tokyo: TERRAPUB. 
21. HAYAKAWA, M., ed., 2009. Electromagnetic phenomena associated with earthquakes. Trivandrum, India: Transworld Research Network.

22. HAYAKAWA, M., ed., 2013. Earthquakes prediction studies: seismo electromagnetic. Tokyo: TERRAPUB.

23. SURKOV, V. and HAYAKAWA, M., 2014. Ultra and Extremely Low Frequency Electromagnetic Fields. Tokyo, Heidelberg, New York, Dordrecht, London: Springer Japan.

24. GOKHBERG, M. B. and SHALIMOV, S. L., 2008. The Impact of Earthquakes and Explosions on the Ionosphere. Moscow, Russia: Nauka Publ. (in Russian).

25. CHERNOGOR, L. F., 2012. Physics and Ecology of Disasters. Kharkiv, Ukraine: V. N. Karazin Kharkiv National University Publ. (in Russian).

26. CHERNOGOR, L. F. and GARMASH, K. P., 2018. Magnetospheric and Ionospheric Effects Accompanying the Strongest Technogenic Catastrophe. Geomagn. Aeron. vol. 58, no. 5, pp. 673-685. DOI: $10.1134 / \mathrm{S} 0016$ 793218050031

27. CHERNOGOR, L. F., 2009. Radiophysical and Geomagnetic Effects of Rocket Engine Burn: Monograph. Kharkiv, Ukraine: V. N. Karazin Kharkiv National University Publ. (in Russian).

28. CHERNOGOR, L. F. and BLAUNSTEIN, N., 2013. Radiophysical and Geomagnetic Effects of Rocket Burn and Launch in the Near-the-Earth Environment. Boca Raton, London, New York: CRC Press. Taylor \& Francis Group.

29. CHERNOGOR, L. F., 2016. Possibility Action of Rocket and Space Engineering Launches on Earth's Magnetic Field. In: V. V. ADUSHKIN, S. I. KOZLOV, and M. V. SIL'NIKOV, eds. Rocket and Space Engineering Action on Environment. Moscow, Russia: GEOS Publ. (in Russian).

30. CHERNOGOR, L. F., VERTOGRADOV, G. G., URYADOV, V. P., VERTOGRADOVA, E. G. and SHAMOTA, M. A., 2010. Consistent Quasi-Periodic Variations of the Geomagnetic Pulsation Level and Doppler Frequency Shift of Decametric Radio Waves Aspect-Scattered by Artificial Field-Aligned Ionospheric Irregularities. Radiophys. Quantum Electron. vol. 53, no. 12, pp. 688-705. DOI: 10.1007/s11141-011-9262-z

31. CHERNOGOR, L. F., 2014. Physics of High-Power Radio Emissions in Geospace: Monograph. Kharkiv, Ukraine: V. N. Karazin Kharkiv National University Publ. (in Russian).

32. CHERNOGOR, L. F., 2019. Geomagnetic Disturbances Accompanying the Great Japanese Earthquake of March 11, 2011. Geomagn. Aeron. vol. 59, no. 1, pp. 62-75. DOI: $10.1134 / \mathrm{S} 0016793219010043$

33. CHERNOGOR, L. F., 2019. Possible Generation of Quasi-Periodic Magnetic Precursors of Earthquakes. Geomagn. Aeron. vol. 59, no. 3, pp. 374-382. DOI: 10.1134/ S001679321903006X

34. CHERNOGOR, L. F., 2003. Physics of Earth, Atmosphere, and Geospace from the Standpoint of System Paradigm. Radio Phys. Radio Astron. vol. 8, no. 1, pp. 59-106. (in Russian).

35. CHERNOGOR, L. F., 2006. The Earth - atmosphere ionosphere - magnetosphere as an open dynamic non-linear physical system. 1. Nelineinyi Mir. vol. 4, no. 12, pp. 655-697. (in Russian).
36. CHERNOGOR, L. F., 2007. The Earth - atmosphere ionosphere - magnetosphere as an open dynamic nonlinear physical system. 2. Nelineinyi Mir. vol. 5, no. 4, pp. 198-231. (in Russian).

37. CHERNOGOR, L. F. and ROZUMENKO, V. T., 2008. Earth - Atmosphere - Geospace as an Open Nonlinear Dynamical System. Radio Phys. Radio Astron. vol. 13, is. 2 , pp. $120-137$.

38. CHERNOGOR, L. F., 2011. The Earth-atmospheregeospace system: main properties and processes. Int. J. Remote Sens. vol. 32, is. 11, pp. 3199-3218. DOI: 10.1080/ 01431161.2010 .541510

39. GUO, Q., CHERNOGOR, L. F., GARMASH, K. P., ROZUMENKO, V. T. and ZHENG, Y., 2019. Dynamical processes in the ionosphere following the moderate earthquake in Japan on 7 July 2018. J. Atmos. Sol.-Terr. Phys. vol. 186, pp. 88-103. DOI: 10.1016/j.jastp.2019.02.003

40. LUO, Y., GUO, Q., ZHENG, YU, GARMASH, K. P., CHERNOGOR, L. F. and SHULGA, S. M., 2019. HF radio-wave characteristic variations over China during moderate earthquake in Japan on September 5, 2018. Visnyk of V. N. Karazin Kharkiv National Universit. Ser. Radio Physics and Electronics. vol. 30, pp. 16-26. (in Ukrainian). DOI: 10.26565/2311-0872-2019-30-02

41. LUO, Y., GARMASH, K. P., CHERNOGOR, L. F. and SHULGA, S. M., 2019. Geomagnetic field fluctuations during Chuysk earthquakes on September - October, 2003. Visnyk of V. N. Karazin Kharkiv National University. Ser. Radio Physics and Electronics. vol. 31, pp. 87-104. (in Russian). DOI: 10.26565/2311-0872-2019-31-09

42. LUO, Y., CHERNOGOR, L. F., GARMASH, K. P., GUO, Q. and ZHENG, YU., 2020. Seismic-Ionospheric Effects: Results of Radio Soundings at Oblique Incidence. Radio Phys. Radio Astron. vol. 25, no. 3, pp. 218-230. (in Ukrainian). DOI: 10.15407/rpra25.03.218

43. MOORE, G. W., 1964. Magnetic Disturbances preceding the 1964 Alaska Earthquake. Nature. vol. 203, pp. 508-509. DOI: $10.1038 / 203508$ b0

44. VOROB'EV, A. A., 1970. On the possibility of electric discharges in the Earth's interiors. Geologiya i Geofizika. no. 12 , pp. 3-13. (in Russian).

45. GOGATISHVILI, YA. M., 1984. Geomagnetic precursor of intensive earthquakes in the spectrum of geomagnetic pulsations with frequencies of $1-0.02 \mathrm{~Hz}$. Geomagn. Aeron. vol. 24, no. 4, pp. 697-700. (in Russian).

46. SIDORIN, A. YA., 1992. Earthquake Precursors. Moscow, Russia: Nauka Publ. (in Russian).

47. SOBISEVICH, L. E., KANONIDI, K. KH. and SOBISEVICH, A. L., 2009. Ultra low-frequency electromagnetic disturbances appearing before strong seismic events. Dokl. Earth Sci. vol. 429, no. 5, pp. 1549-1552. DOI: 10.1134/S1028334X09090281

48. SOBISEVICH, L. E., SOBISEVICH, A. L. and KANONIDI, K. KH., 2012. Anomalous geomagnetic disturbances induced by catastrophic tsunamigenic earthquakes in the region of Indonesia. Geofizicheskiy Zhurnal. vol. 34, no. 5, pp. 22-37. (in Russian). DOI: 10.24028/gzh.0203-3100. v34i5.2012.116661

49. SOBISEVICH, L. E., KANONIDI, K. KH., SOBISEVICH, A. L. and MISEYUK, O. I., 2013. Geomagnetic Disturbances in the Geomagnetic Field's Variations at Sta- 
ges of Preparation and Implementation of the Elazig (March 8, 2010) and M 5.3 (January 19, 2011) Earthquakes in Turkey. Dokl. Earth Sci. vol. 449, no. 1, pp. 324-327. DOI: $10.1134 / \mathrm{S} 1028334 X 13030069$

50. SOBISEVICH, A. L., STAROSTENKO, V. I., SOBISEVICH, L. E., KENDZERA, A. V., SHUMAN, V. N., VOL'FMAN, YU. M., POTEMKA, E. P., KANONIDI, K. KH. and GARIFULIN, V. A., 2013. The Black Sea earthquakes of late December 2012 and their manifestations in the geomagnetic field. Geofizicheskiy Zhurnal. vol. 35, no. 6, pp. 54-70. (in Russian). DOI: 10.24028/ gzh.0203-3100.v35i6.2013.116455

51. SOBISEVICH, L. E., SOBISEVICH, A. L. and KANONIDI, K. KH., 2015. Some anomalous geospheric processes during preparation and development of seismic events. Trigger effects in geospheres. In: V. V. ADUSHKIN and G. G. KOCHARYAN, eds. Proceedings of the Third AllRussian Workshop-Meeting. Moscow, Russia: GEOS Publ. (in Russian).

52. FRASER-SMITH, A. C., BERNARDI, A., MCGILL, P. R., LADD, M. E., HALLIWELL, R. A. and VILLARD, O. G., Jr., 1990. Low-frequency magnetic field measurements near the epicenter of the M 7.1 Loma Prieta Earthquake. Geophy. Res. Lett. vol. 17, is. 9, pp. 1465-1468. DOI: 10.1029/ GL017i009p01465

53. CAMPBELL, W. H., 2009. Natural magnetic disturbance fields, not precursors, preceding the Loma Prieta earthquake. J. Geophys. Res. Spase Phys. vol. 114, is. A5, id. A05307. DOI: 10.1029/2008JA013932

54. SHESTOPAlOV, I. P., BELOV, S. V., SOLOVIEV, A. A. and KUZMIN, YU. D., 2013. Neutron generation and geomagnetic disturbances in connection with the Chilean earthquake of February 27, 2010 and a volcanic eruption in Iceland in March-April 2010. Geomagn. Aeron. vol. 53, no. 1, pp. 124-135. DOI: 10.1134/S0016793213010179

55. ROMANOVA, N. V., PILIPENKO, V. A. and STEPANOVA, M. V., 2015. On the magnetic precursor of the Chilean earthquake of February 27, 2010, Geomagn. Aeron. vol. 55, no. 2 , pp. 219-222. DOI: 10.1134/S00167 93215010107

56. MOLCHANOV, O. A., KOPYTENKO, YU. A., VORONOV, P. M., KOPYTENKO, E. A., MATIASHVILI, T. G., FRASER-SMITH, A. C. and BERNARDI, A., 1992. Results of ULF magnetic field measurements near the epicenters of the Spitak $\left(\mathrm{M}_{s}=6.9\right)$ and Loma Prieta $\left(\mathrm{M}_{s}=7.1\right)$ earthquakes: Comparative analysis. Geophys. Res. Lett. vol. 19, is. 14, pp. 1495-1498. DOI: 10.1029/92GL01152

57. KOPYTENKO, YU. A., MATIASHVILI, T. G., VORONOV, P. M., KOPYTENKO, E. A. and MOLCHANOV, O. A., 1993. Detection of ultra-low-frequency emissions connected with the Spitak earthquake and its aftershock activity, based on geomagnetic pulsations data at Dusheti and Vardzia observatories. Phys. Earth Planet. Inter. vol. 77, is. 1-2, pp. 85-5. DOI: 10.1016/00319201(93)90035-8

58. HAYAKAWA, M., KAWATE, R., MOLCHANOV, O. A. and JUMOTO, K., 1996. Results of ultra-low-frequency magnetic field measurements during the Guam earthquake of 8 August 1993. Geophys. Res. Lett. vol. 23, is. 3, pp. 241-244. DOI: 10.1029/95GL02863
59. SCHEKOTOV, A., FEDOROV, E., HOBARA, Y. and HAYAKAWA, M., 2013. ULF Magnetic Field Depression as a Possible Precursor to the 2011/3.11 Japan Earthquake. J. Atmos. Electr. vol. 33, is. 1, pp. 41-51. DOI: 10.1541/ jae.33.41

60. SCHEKOTOV, A., FEDOROV, E., HOBARA, Y. and HAYAKAWA, M., 2013. ULF magnetic field depression as a possible precursor to the 2011/3.11 Japan earthquake. Radiofiz. Electron. vol. 4(18), no. 1, pp. 47-52.

61. FRASER-SMITH, A. C., MCGILL, P. R., HELLIWELL, R. A. and VILLARD, O. G., Jr., 1994. Ultra-low frequency magnetic field measurements in southern California during the Northridge Earthquake of 17 January 1994. Geophys. Res. Lett. vol. 21, is. 20, pp. 2195-2198. DOI: 10.1029/94GL01984

62. KARAKELIAN, D., KLEMPERER, S. L., FRASERSMITH, A. C. and THOMPSON, G. A., 2002. Ultra-low frequency electromagnetic measurements associated with the $1998 \mathrm{M}_{w}=5.1$ San Juan Bautista, California earthquake and implications for mechanisms of electromagnetic earthquake precursors. Tectonophysics. vol. 359, is. 1-2, pp. 65-79. DOI: 10.1016/S0040-1951(02)00439-0

63. FRASER-SMITH, A. C., 2008. Ultralow-Frequency Magnetic Fields Preceding Large Earthquakes. Eos. vol. 89, no. 23, p. 211. DOI: 10.1029/2008EO230007

64. PARK, S. K., JOHNSON, M. J. S, MADDEN, T. R., MORGAN, F. D. and MORRISON, H. F., 1993. Electromagnetic precursors to earthquakes in the ULF band: A review of observations and mechanisms. Rev. Geophys. vol. 31 , is. 2, pp. 117-132. DOI: 10.1029/93RG00820

65. GELLER, R. J., 1997. Earthquake prediction: a critical review. Geophys. J. Int. vol. 131, is. 3, pp. 425-450. DOI: 10.1111/j.1365-246X.1997.tb06588.x

66. BAKUN, W. H., AAGAARD, B., DOST, B., ELLSWORTH, W. L., HARDEBECK, J. L., HARRIS, R. A., J, C., JOHNSTON, M. J. S., LANGBEIN, J., LIENKAEMPER, J. J., MICHAEL, A. J., MURRAY, J. R., NADEAU, R. M., REASENBERG, P. A., REICHLE, M. S., ROELOFFS, E. A., SHAKAL, A., SIMPSON, R. W. and WALDHAUSER, F., 2005. Implications for prediction and hazard assessment from the 2004 Parkfield earthquake. Nature. vol. 437, pp. 969-974. DOI: 10.1038/nature04067

67. KOSTERIN, N. A., PILIPENKO, V. A. and DMITRIEV, E. M., 2015. On global ultralow frequency electromagnetic signals prior to earthquakes. Geophysical Research. vol. 16, no. 1, pp. 24-34. (in Russian).

68. BAKHMUTOV, V. G., SEDOVA, F. I. and MOZGOVAYA, T. A., 2003. Morphological analysis of geomagnetic variations in preparation period of the strongest earthquake of 25 March 1998 in Antarctic. Ukrainian Antarktic Journal. no. 1, pp. 54-60. (in Russian).

69. SURKOV, V. V. and PILIPENKO, V. A., 1997. Magnetic effects due to earthquakes and underground explosions: a review. Ann. Geophys. vol. 40, no. 2, pp. 227-239. DOI: 10.4401/ag-3904

70. GUGLIELMI, A. V., 2007. Ultra-low-frequency electromagnetic waves in the Earth's crust and magnetosphere. Phys.-Uspekhi. vol. 50, is. 12, pp. 1197-1216. DOI: 10.1070/PU2007v050n12ABEH006413

71. PUlinetS, S. A., OUZOUNOV, D. P., KARELIN, A. V. and DAVIDENKO, D. V., 2015. Physical bases of the ge- 
neration of short-term earthquake precursors: A complex model of ionization-induced geophysical processes in the lithosphere-atmosphere-ionosphere-magnetosphere system. Geomagn. Aeron. vol. 55, is. 4, pp. 521-538. DOI: 10.1134/S0016793215040131

72. CHERNOGOR, L. F., 2008. Advanced Methods of Spectral Analysis of Quasiperiodic Wave-Like Processes in the Ionosphere: Specific Features and Experimental Results. Geomagn. Aeron. vol. 48, is. 5, pp. 652-673. DOI: 10.1134/ S0016793208050101

73. KULICHKOV, S. N., 1992. Long-range sound propagation in the atmosphere (Review). Rossiiskaia Akademiia Nauk, Izvestiia, Fizika Atmosfery i Okeana. vol. 28, no. 4, pp. 339-360. (in Russian).

74. Le PICHON, A., BLANC, E. and HAUCHECORNE, A., eds., 2010. Infrasound monitoring for atmospheric studies. Dordrecht, Heidelberg, London, New York: Springer Int. Publ. DOI: 10.1007/978-1-4020-9508-5

\section{Y. Luo, L. F. Chernogor, and K. P. Garmash}

V. N. Karazin Kharkiv National University, 4, Svoboda Sq., Kharkiv, 61002, Ukraine

\section{GEOMAGNETIC EFFECT OF TURKISH EARTHQUAKE OF JANUARY 24, 2020}

Purpose: The main cause of geomagnetic disturbances are cosmic sources, processes acting in the solar wind and in the interplanetary medium, as well as large celestial bodies entering the terrestrial atmosphere. Earthquakes (EQs) also act to produce geomagnetic effects. In accordance with the systems paradigm, the Earth-atmosphere-ionosphere-magnetosphere system (EAIMS) constitute a unified system, where positive and negative couplings among the subsystems, as well as feedbacks and precondition among the system components take place. The mechanisms for the action of EQs and processes acting in the lithosphere on the geomagnetic field are poorly understood. It is considered that the EQ action is caused by cracking of rocks, fluctuating motion in the pore fluid, static electricity discharges, etc. In the course of EQs, the seismic, acoustic, atmospheric gravity waves (AGWs), and magnetohydrodynamic (MHD) waves are generated. The purpose of this paper is to describe the magnetic effects of the EQ, which took place in Turkey on 24 January 2020.

Design/methodology/approach: The measurements are taken with the fluxmeter magnetometer delivering $0.5-500 \mathrm{pT}$ sensitivity in the $1-1000$ s period range, respectively, and in a wide enough studied frequency band within 0.001 to $1 \mathrm{~Hz}$. The EM-II magnetometer with the embedded microcontroller digitizes the magnetometer signals and performs preliminary filtering over $0.5 \mathrm{~s}$ time intervals, while the external flash memory is used to store the filtered out magnetometer signals and the times of their acquisition. To investigate quasi-periodic processes in detail, the temporal variations in the level of the $H$ and $D$ components of the geomagnetic field were applied to the systems spectral analysis, which makes use of the short-time Fourier transform, the wavelet transform using the Morlet wavelet as a basis function, and the Fourier transform in a sliding window with a width adjusted to be equal to a fixed number of harmonic periods.

Findings: The train of oscillations in the level of the $D$ component observed $25.5 \mathrm{~h}$ before the EQ on 23 January 2020 is supposed to be associated with the magnetic precursor. The bidirectional pulse in the $H$ component observed on 24 January 2020 could be due to the piston action of the EQ, which had generated an MHD pulse. The quasi-periodic variations in the level of the $H$ and $D$ components of the geomagnetic field, which followed 75 min after the EQ, were caused by a magnetic disturbance produced by the traveling ionospheric disturbances due to the AGWs launched by the EQ. The magnetic effect amplitude was estimated to be close to $0.3 \mathrm{nT}$, and the quasi-period to be 700-900 s. The amplitude of the disturbances in the electron density in the AGW field was estimated to be about $8 \%$ and the period of 700-900 s. Damping oscillations in both components of the magnetic field were detected to occur with a period of approximately $120 \mathrm{~s}$. This effect is supposed to be due to the shock wave generated in the atmosphere in the course of the EQ.

Conclusions: The magnetic variations associated with the EQ and occurring before and during the EQ have been studied in the $1-1000$ s period range.

Key words: earthquake, fluxmeter magnetometer, quasi-periodic disturbance, seismic wave, acoustic-gravity wave, MHD pulse

Стаття надійшла до редакиії 11.08.2020 